\title{
PROCESSES USED IN THE CREATION OF ANTHROPONYMS IN OLD HUNGARIAN ${ }^{1}$
}

\section{THE HISTORY OF PERSONAL NAME-FORMATION IN HUNGARIAN}

It is a widely known axiom that proper names are present in the languages of all peoples, that is, they are linguistic and cultural universals. This is the reason why the cultural and social context in which a name system works determines its character and development. Of all proper names, it is personal names that react the most sensitively to new external influences; that is, they immediately introduce changes into elements of the name system. The explanation for this phenomenon is that personal names belong mostly to closed and small communities and their lifespan is relatively short since they function as long as the named person lives. While names in the system of Hungarian personal names were formed from Hungarian common words and loans from Turkish languages during the Hungarian Conquest and the preceding Migration Period, German and Slavic elements and name-giving patterns also appeared in the Hungarian system following the settlement in the Carpathian Basin as a result of co-habitation with neighbouring peoples. The introduction of Christianity in the $10^{\text {th }}$ century was a definitive change in cultural history because the Hungarian state joined the European Christian-feudal cultural context. Cultural influences thus also induced changes in the system of personal names. Changes in the language system and the name system imply that there is a period while old and new elements live in parallel and influence each other for a time and then one of them becomes dominant and determinative. Changes can be best traced by examining the remaining language records from the given period.

In this essay, I will present the system of personal names using the sporadic record of the Census of the Abbey of Tihany that dates back to the $13^{\text {th }}$ century

1 This work was carried out as part of the Research Group on Hungarian Language History and Toponomastics (University of Debrecen-Hungarian Academy of Science). 
(PRT. 10, pp. 502-17). The Census of the Abbey of Tihany is also related to our oldest remaining written source, which is the Founding Charter of the Abbey of Tihany from 1055, since it re-establishes the outdated perambulations in the Charter. The Census of the Abbey of Tihany was drafted in 1211 under the supervision of King Andrew II who conducted a Census about the properties and people of the Abbey of Tihany. The Census of the Abbey of Tihany is an invaluable source as we have very few scattered records of Hungarian from before 1211 . Since this Latin text is rich in Hungarian place and personal names, it is one of the most important sources of the history of Hungarian personal names. This legal act refers to as many as 2,000 individuals who lived and served on the 37 properties belonging to the Abbey of Tihany. In most cases, their occupation and family/ generation relations are also indicated in the Charter, thus informing us about the name-giving act. By the $13^{\text {th }}$ century, Christianity, the kingdom, the division of properties and the common properties of families were all confirmed in Hungary and this affected names as well. In this era names formed from elements of the Hungarian language are still present in relatively large numbers, but they are frequently replaced mainly by Christian Latin (Biblical, martyrological) names and also by German, Slavic, or perhaps Turkish names.

The formation of personal names in the Hungarian language was done by means of several name-formation processes in the Middle Ages. When examining the history of the formation of personal names, we look for name-formation rules in action when new personal names are created. Since proper names and their types, including personal names, belong to the linguistic system, their formation and changes submit to the very same trends as those of other linguistic elements. Therefore the pillars on which the typology of the history of the formation of Hungarian personal names rests are the same as the word-formation categories of Hungarian common nouns or those adapted to place names as demonstrated by I. Hoffmann (2007, pp. 79-80, see also Tóth, 2016, pp. 138-140, N. Fodor, 2010, pp. 111-120). Word-formation results from the characteristics of personal names where features and frequency of each type may be different. When examining the formation of old personal names, the important aspect that must be taken into account is that personal names can also be formed on the basis of other proper names (including Hungarian and loaned personal and place names), in addition to common words of the given language. In what follows, I shall present the main name-formation mechanisms of the old Hungarian language on the basis of the personal names of the already mentioned Census of the Abbey of Tihany. I will also examine their frequency and the linguistic and extra-linguistic factors, explaining their differing productivity in the era. 


\section{SEMANTIC NAME-FORMATION}

It is a natural form of expression of the human inclination to create symbols and compare things and, therefore, metaphor and metonymy theories in cognitive linguistics consider that the mental processes of name-formation are characteristic of the elementary creative forces of language and of human thinking and cognizance (Kövecses, 2005, Tolcsvai, 2008, Reszegi, 2009, pp. 21-41). Related to personal names, semantic name-formation means that a string of sounds already present in the language is given a new meaning — that is, a personal name-meaning, thus becoming a personal name, while keeping its original form. Semantic re-evaluation therefore lacks any grammatical construction or change in form. This process includes only nominal elements of the lexis, that is, common nouns or proper names (Hoffmann, 2007, p. 106). Since the bulk of personal names of the early old Hungarian period are names formed from Hungarian common nouns, it is not at all surprising that in this era this method of name-formation became very significant. The semantic name-formation processes in the creation of personal names are described below.

\subsection{Metaphoric name-giving}

In the formation of personal names, metaphoric name-giving means that a feature of the person in question is compared to an entity. Metaphors thus express by comparison some external or internal feature of people (Hoffmann, 2007, p. 128, N. Fodor, 2010, p. 113). Semantic categories of metaphoric names are clearly related to the common word on which the metaphor is based. If the comparison is based on an object or plant, then beauty, toughness, colour or other external features are stressed in comparing the denoted person to them. Since animals can be related to people in certain biological respects, common nouns denoting animals use a wider spectrum of notions and physical capacities (strength, speed, durability), and some features related to certain animals (wisdom, smartness, shyness, benignity, etc.) also appear in addition to external features. In Old Hungarian personal names, a number of common nouns denoting animals, plants and materials can be found, a certain feature of which is assumed to have been the basis of personal names. Since data in the sporadic records of old Hungarian give us very few, if any, clues about the motivation of name-giving, we can only create hypotheses about the circumstances of name formation. If we consider motivations of name-giving processes afterwards as analogies (see family names and nicknames), we may well suppose that some of the names were based on metaphoric name-giving, although other name-formation processes may also have contributed to their formation. 


\subsubsection{Personal names formed from common nouns denoting animals}

Some personal names formed from animals are assumed to have been formed using this name-giving method. In the early old Hungarian era, humans and nature were very closely related. Even now, it often happens that features attributed to certain animals appear in common similes, e.g., He drinks like a pelican. He is quick like a rabbit. A weak-hearted rabbit. He is vulpine like a fox. He is benign like a pigeon etc. (these are Hungarian examples). Therefore, people with features comparable to those of animals were often given animal names in previous times. In some cases, it can almost certainly be established which alleged feature of an animal was the basis for name-giving. Personal names Medve, Farkas, Bika, meaning 'bear', 'wolf', 'bull' respectively, may have referred to physical strength, while Galamb meaning 'pigeon' would refer to benignity or victimization, and Róka meaning 'fox' would mean clever, smart, or vulpine.

The Census of the Abbey of Tihany contains several personal names formed from animal names that lead us to suppose that the animal and the person were similar in some way to one another. See bogár 'bug' > Bogár (PRT. 10: Bogar) personal name (henceforth PN), kánya 'goshawk'> Kánya PN (PRT. 10: Cana), rigó 'mockingbird' > Rigó PN (PRT. 10: Rigou), patkány 'rat' > Patkány PN (PRT. 10: Potcan), ravasz 'fox, smart' > Ravasz PN (PRT. 10: Ruuoz), farkas 'wolf' > Farkas PN (PRT. 10: Forcos, Forcus), medve 'bear' > Medve PN (PRT. 10: Medue, Medueh, Medune, Meduel).

\subsubsection{Personal names formed from common nouns denoting plants}

Apart from common nouns denoting animals, common nouns denoting plants also may refer to a similarity between plants and people. However, plants are less capable of invoking analogy with humans and therefore the number of personal names formed from common nouns denoting plants is far lower. The Census of the Abbey of Tihany mentions only one or two common nouns denoting plants where similarity may have served as the basis for name-giving. See $b a b$ 'bean' > Bab PN (PRT. 10: Bob), kökény 'blackthorn'> Kökény PN (PRT. 10: Cuchen).

Common nouns denoting plants were mostly used as a comparative attribute to women in the Middle Ages and these personal names refer to the fragility and/or the beauty of the women in question or were used to express courtesy, see: Virág 'flower', Liliom 'lily', Rózsa 'rose'.

\subsubsection{Personal names formed from common nouns denoting materials or objects}

Albeit rarely, common nouns denoting materials or objects might also have referred to some similarity with human features. See vas 'iron' common noun 
denoting a material $>$ Vas 'strong man' PN (PRT. 10: Vossa, Wosa, Vosod, Wosud), réz 'copper' common noun denoting a material > Réz 'red-haired man' PN (PRT. 10: Reze, Rezed).

\subsection{Metonymic name-giving}

In cognitive linguistics, metonymy is a cognitive process, its main function being to help conceptualisation. Based on contiguity, metonymy enables us to use (to refer to) one part or aspect of a concept to provide access to some other part (or the whole) of that concept (cf. Reszegi, 2012, pp. 367-379). In the name-giving act it means that the common noun denoting a notion becomes the name of a person without formal changes. The relationship of the two notions helps to determine the types of metonymic name-giving (Hoffmann, 2007, pp. 118-127, N. Fodor, 2010, pp. 113-114, Tóth, 2016, pp. 138-140). In the following section, I will present the most typical examples of personal names based on metonymy in Hungarian.

\subsubsection{Personal names derived from occupations where the object, the tool, the subject or a specific action of the occupation appears}

In old Hungarian, it was typical that people were named after their occupation. Apart from the common noun denoting an occupation, it often happened that common nouns denoting phenomena within the range of notions of the given occupation were also used as personal names. Animals, plants, objects, materials or actions related to the given occupation often serve as the basis for metonymy. A frequently mentioned example in Hungarian linguistics is Péter the butcher who on one occasion was referred to by his occupation as Ökör (1330: Petri carnificis dicti Wkur) 'ox' and on another - by the produce he made as Kolbász (1373: Petri carnificis dicti Kolbaz) 'sausages' (Ok1Sz., N. Fodor, 2010, p. 114). The Census of the Abbey of Tihany features several similar examples:

A peasant was called Bak 'buck': "In villa Ozoufeu (Ozoufeuh) hii sunt agricole: [...] filii Nuetlen, Bocu, Topsa" (PRT. 10, p. 505).

In a village called Besenyö, some fishermen were named after fish, see Sügér 'perch' and Ön 'asp' and his son was called Süllö 'sander': "In villa Beseneu [...] isti sunt curriferi: filius Bodor, Cuche; filii Syguer (Suguer), Buhte (Buhteh), Botus; filius Eunen, Sileu (Silleu)" (PRT. 10, p. 510).

Wine producers were called Bor 'wine', Örzö 'keeper' and Csomoszló 'crushing': "In villa Pilip hii sunt vinitores: [...] Pata cum filio suo Mogud (Mocud); et Bor ioubagio cum filiis, Andrea et Zaazlou" (PRT. 10, p. 507); "In villa Theluky (Tehluki) sunt isti vinitores ecclesie: [...] filii Kerus, Gunuzd (Keres, Gunuzt) 
cum filio suo Mathia, frater eius Euruzeu (Eurizen) cum filio suo Michou; filius Joan, Chomoslou (Chomozlau) cum filio suo Henche" (PRT. 10, p. 514). Bor refers to the occupation by naming the product of the vineyard, while the names Örzö and Csomoszló associate the person with the working processes of wine production. Örzö refers to the management of the product while Csomoszló (derived from the verb csomoszol) refers to the mashing before the pressing of grapes.

A smith named Vas 'iron' may have been named after the material he processed: "[In Tychon] [...]. Fabri vero sunt hii: filius Petesse, Methe, cum filiis suis: Cheb, Wus" (PRT. 10, p. 503).

One of the half-free serfs, who were often responsible for the provision of meal and bread, was called Aratás 'harvest': "In villa Supoc hii sunt vdornicij: [...] filii Vasaard (Vasard), Somciu, Aratas" (PRT. 10, p. 513).

Of course, we cannot assert that these names refer to the occupation of the person in every case since another contact may have also served as the basis of the name-giving (possession, event, feature, etc., cf. N. Fodor, 2010, p. 114). Still, the appearance within a family of names from a similar range of meanings may allow us to conclude that it was highly probable that the name-giving act in question was related to the occupation of the person.

\subsubsection{Names referring to social relationship, kinship, succession and certain events}

The basis of metonymic name-giving might have also been a position name but in such cases it was rather the social relationships and not the rank of the person the name refers to. A good example is the name Király 'king' referring to peasants (1389: Johannis dictis Kyral, Zs. 1: 112/944, Fehértói, 1969, p. 104, cf. Tóth, 2016, p. 139). The Census of the Abbey of Tihany does not contain examples of such name-giving acts. But some suppose that the personal names Ajándék 'gift' (PRT. 10: Aianduc Aihanduc) and Vásár 'fair' (PRT. 10: Vasar, Vasard, Vasaard, Wasard) refer to the circumstances of acquiring certain lower-ranked servants (Pais, 1966, p. 23). Others think that these names refer to the circumstances of their birth (Hajdú, 2003, p. 352).

Names denoting kinship, succession, or family relationships are also metonymic. The Census of the Abbey of Tihany contains numerous examples of this type of name. Kinship is referred to in the names Unoka 'grandchild' (PRT. 10: Vnoca Hunoca, Vnuca, Wnoca) and Ös 'ancestor' (PRT. 10: Ws, Vus).

The order of birth or the children's role within the family may be connoted by the names Hármas 'number three' (PRT. 10: Harmas), Hét 'seven' (PRT. 10: Het, Heteh), Hatos, Hat 'number six, six' (PRT. 10: Hotus), Kettös 'twin or second 
child' (PRT. 10: Keteus), Négy 'four' (PRT. 10: Nege), Tíz 'ten' (Tize), Öt 'five' (Vteh), Maradék 'remaining alive' (PRT. 10: Maradic).

Important events (e.g. birth) in life are often associated with the names of days or holidays. The Charter contains the personal names Húsvét 'Easter' (PRT. 10: Hosued, Cysveth), Karácsony 'Christmas' (PRT. 10: Karasun, Karachun, Karachyn), Péntek 'Friday' (PRT. 10: Pentec, Pentuc), Szerda 'Wednesday' (PRT. 10: Zereda) and Szombat 'Saturday' (PRT. 10: Zombot, Sombod). Maybe the name Csoda 'miracle' (PRT. 10: Coda) also refers to the circumstances of the person's birth if these were extraordinary.

\subsubsection{Place name elements in personal names}

The basis of personal names formed by metonymy might have been a proper name instead of a common word, albeit rarely. It was mostly place names that appear in such a role since the relationship of the person with certain places often motivated his/her name. Personal names formed on the basis of place names were mostly reduced or derived, that is, a formal change took place. However, in some rare cases metonymy might also have served the name-giving act (cf. Tóth, 2016, p. 139). Perhaps this was how Szölös (PRT. 10: Zeuleus), the half-free serf living in Szántó, Gyóta (PRT. 10: Jouta), the bell-ringer living in Petra, Tihany (PRT. 10: Tichon), the peasant living in Aszófö, or Becsej (PRT. 10: Beccey), the villein living in Örményes were named. All these names also occur in the Charter as place names: "[...] in loco, qui vulgo dicitur Tychon" (PRT. 10, p. 502); "In territorio Simigiensis castri ultra Jouta in villa Sagh" (PRT. 10, p. 512); "in villa Zeleus" (PRT. 10, p. 506); "et inde transiens Bechey" (PRT. 10, p. 509). It cannot be asserted that this is how these personal names were formed but the possibility cannot be excluded either.

\subsubsection{Pars pro toto type personal names}

Pars pro toto type names, that is, those denoting a part/total relationship are a special type of metonymic name-giving. This type of act is frequent among place names as well, when a part of a landscape or the name of a point-like place becomes the proper name of a larger territory (Hoffmann, 2007, p. 121). This semantic relationship is often reflected in old Hungarian personal names that typically identified people with a part of the human body or referred to a bodily transformation (Tóth, 2016, p. 139). The Census of the Abbey of Tihany contains some examples of people named after a part of the human body or by referring to a bodily transformation, without a derivative. This semantic relationship is 
expressed in the names Szem 'eye' (PRT. 10: Zeme), Haj 'hair' (PRT. 10: Haia) and Csipa 'rheum' (PRT. 10: Chypa). Such common words often served as the basis of personal names but since most of the latter are formed by the derivation of common words, the formation of such names as Horrod and Hoiud formed by derivation from common words orr and haj, or personal names Semes, Semchi, Semd, Semech, Zemse, Zemd, Zemchi formed from the common word szem, can be attributed to morphematic construction.

\subsection{Semantic split}

The most general type of personal names formed from common words without a formal change is that of semantic split, which means that a common word that in itself is suitable for denoting a person without a formant becomes a personal name. During this change, the name-users also interpret the common word as one denoting a certain person (Hoffmann, 2007, p. 108). In most cases, ethnonyms, occupations, or lexemes denoting a feature or a person can be used as personal names in such a function (N. Fodor, 2010, p. 115, Tóth, 2016, pp. 139-140). The Census of the Abbey of Tihany contains a large number of personal names formed this way, see tatár 'Tatar' > Tatár PN (PRT. 10: Tatar), lengyel 'Pole'> Lengyel PN (PRT. 10: Lengen), pogány 'pagan'> Pogány PN (PRT. 10: Pagan), vendég 'guest' > Vendég PN (PRT. 10: Wendeg, Vendug, Wendech, Vendek), legény 'bachelor'> Legény PN (PRT. 10: Leguine), táltos 'shaman' > Táltos PN (PRT. 10: Tholtus), szöke 'blonde'> Szöke PN (PRT. 10: Zeuke), korom 'grime' > Korom PN (PRT. 10: Corom), magas 'tall'> Magas PN (PRT. 10: Mogus), vak 'blind'> Vak PN (PRT. 10: Vocu, Voci), erös 'strong' > Erös PN (PRT. 10: Ereus), boldog 'happy' > Boldog PN (PRT. 10: Bondug Boudug), hazug 'liar'> Hazug PN (PRT. 10: Hozug), szomorú 'sad' > Szomorú PN (PRT. 10: Somorou, Summorav $\sim$ Summorau).

Efforts to achieve language economy in the case of personal names contributed considerably to the fact that semantic name-formation was very common in the early Old Hungarian era. Besides, the large number of names formed with this "ancient" name-giving method demonstrates that man and nature had a relatively close organic relationship in that age. It is quite evident that we cannot be cautious enough when stating any motivation of name-givers in the name-giving act when names and people were correlated. These categories and the related examples reflect an organization that I consider possible. I must, however, underscore that the border line between semantic types is extremely narrow. It is quite difficult to state, for example, whether the personal name Bika formed on the basis of the common word bika 'bull' is the result of name-giving based on a metaphor, 
metonymy or a semantic split. However, patterns of name-giving within families and the occupations of people listed in the Census of the Abbey of Tihany might help us categorize these names. It cannot be mere chance that the grandchildren of a half-free serf living in the village Csopak are named Farkas 'wolf' and Medve 'bear'. The multiple occurrences of illnesses within a family are reflected by the fact that the servant named Csipa 'rheum' living in the property called Kolon had two siblings called Vak 'blind' (Pais, 1966, p. 12). The fact that in the early Old Hungarian era people's occupation was frequently related to their identification within their communities is well demonstrated by the names of fishermen Süllö 'bass', Ön 'asp', Sügér 'perch' or the wine producer called Bor 'wine' in the Charter.

\section{NAMES FORMED WITH MORPHEMATIC CONSTRUCTION}

Morphematic construction means that a linguistic element (a common word or a proper name) becomes suitable for fulfilling the role of a personal name by derivation (cf. Hoffmann, 2007, p. 85, N. Fodor, 2010, p. 117, Tóth, 2016, p. 140). A large number of our Old Hungarian personal names were formed by derivation. High frequency of this phenomenon is mostly accounted for by the fact that the creation of personal names gave way to the fantasy and linguistic inventions of speakers so it was natural that a numerous cluster of derivatives were introduced in addition to the most frequent derivatives occurring in personal names from the oldest times (Szegfü, 1991, p. 250). Old Hungarian personal names had two basic sources. First, personal names were loaned from other languages in their original form or somehow adapted. Second, common words of the Hungarian language could be used as the basis of personal names, using several name formation rules (cf. Hoffmann, 2008, p. 16). I will offer some examples illustrating the differences between these two ways of name-formation in names formed using a morphematic construction below.

\subsection{Personal names formed from loan names by derivation}

Derived personal names can be formed from names loaned to Hungarian from other languages as elements of the Hungarian system of personal names. In the Census of the Abbey of Tihany, a number of Latin or Greek names (Stephanus, Thomas, Salamon, Petrus etc.) appear among loan names due to the expansion of Christianity, but there are also a few names of Slavic (Ladizlaus, Kazmerio, Gud, Rada etc.), German (Lodomir, Syquid, Wolter $\sim$ Wolterh, Wilmos $\sim$ Vilmos etc.), and Turkish (Tiuan Tiwan Tjuan, Beche etc.) origin. Most loans have a Hungarian form (shortened or derived, that is, they have undergone Hungarian 
name-formation). Hungarian personal names formed from loaned names are special in that Hungarian derivative morphemes are affixed to the shortened form of loans in almost every case, and therefore both morphological means, that is, derivation and name shortening, had an important role in adapting loans into the Hungarian system of personal names.

Some names lack the Latin - us suffix, and are thus to be found in their adapted Hungarian form in historic records: Stephanus $>$ Stephan, Sebastianus $>$ Sebastian, Petrus $>$ Peter, Paulus $>$ Paul, Benedictus $>$ Beneduc etc. However, most names were adapted as a result of name-forming processes within the onymic system of the Hungarian language. During name-shortening, only the first part of the given name remains, in a monosyllabic or disyllabic, closed or open form. Most shortened forms are of the monosyllabic closed type (Ant $<$ Antonius, Pet $<$ Petrus, $F y l<$ Philippus etc.), and these were the ones that mostly underwent further derivation (Benkö, 1950, pp. 230-231). Some loaned names, mainly the church Latin ones, were very frequently used in the Middle Ages, which is also strikingly confirmed by the Census of the Abbey of Tihany.

Below, by means of a few frequent loan names, I will present how extensive the families of such names in the Charter are, illustrating the derivative elements that were used to adapt them into Hungarian (the number after the name indicates the number of occurrences of the personal name in the Charter). Sometimes, such names appear in the Charter in their full original Latin form. In my opinion, these are not real forms in actual use at the time, but the product of the Latinizing efforts of the drafter:

- $\quad$ Benedictus > Ben-ch, Ben-che, Ben-cheh, Ben-e (5), Benedicto (2), Beneduc (6), Ben-se (2)

- Demetrius > Dem-e, Dem-eh (2), Demetrio, Dem-eu, Dem-us, Demetrius

- Jacobus > Jac, Jacob (2), Jacob-o (7), Jacobus (5), Jac-ou (4)

- Johannes > Joan (7), Joan-ca, Joan-chi, Joan-cu, Johan-ca, Johann-e (6), Johann-is (5), Joanus Juanus, Johannes (8)

- Marcellus/Marcus > Marc, Marcel (2), Marcell-i, Marcell-o (2), Marc-i (2), Marc-u (2), Marcus

- $\quad$ Petrus $>$ Pet (6), Pet-e (2), Peter, Pet-es-se, Peth, Peth-e $\sim$ Peth-eh (3), Pet-i, Petr-a, Petr-i (4), Petr-o (7), Petrus (5), Petur (24!), Pet-us (3)

- $\quad$ Sebastianus > Sebastian (2), Sebastian-i (2), Sebastian-o, Sebeh (3)

3.2. Personal names formed from common words by derivation

In personal names formed from Hungarian common words, the derivative is always affixed to the full root of the word. Common words make it possible to denote a feature in name-giving. Onomastics usually considers that these personal 
names were in a close semantic relationship with the common word basis of the name since names were intended to express a specific feature of the person (Benkö, 1967, p. 375). Actually, the same semantic categories appear here as in semantic name-giving, but personal names are formed here by another linguistic means, derivation.

I will present some examples of personal names from the Census of the Abbey of Tihany formed by derivation assigned into the most frequent semantic categories below:

- Personal names formed from plant names: köles 'millet'> Cules-ed, som 'cornel' > Sum-os, Som-od.

- Personal names formed from animal names: agár 'greyhound'> Agar-d, nyúl 'rabbit'> Nul-od.

- Personal names formed from the names of parts of the body: $f o$ " head' $>$ Feuche, haj 'hair' > Hoi-ud. In the Census of the Abbey of Tihany, the most frequent basis for such name-giving is the common word szem 'eye'. This common word is particularly frequent and is affixed with several derivative elements, serving as the basis of personal names not only in this Charter but also in other medieval charters. In this Charter, 14 individuals have names formed from the common word szem, and 13 of these were derived in the following manner: szem 'eye'> Sem-d, Zem-d, Sem-es, Zeme (2), Zem-eh (2), Sem-ech, Zem-chi (2), Sem-chi, Zem-se, Zem-dij etc.

- Personal names formed from kinship names: árva 'orphan'> Árua-d, fia 'son' $>$ Fia-cha.

- Personal names related to human character, human nature, external features: hitvány 'worth nothing' > Hyduan-d Hituan-d, hazug 'liar' > Hozog-a, Hozug-a, gonosz 'wicked' > Gunuz-d, kemény 'hard'> Kemen-d.

- Personal names related to the social situation: munka 'work'> Munca-t (3), vásár 'fair' > Wasar-d (3), Wassar-d, Vasar-d (2), Vasaar-d (3), Vaasar-d.

- Personal names relating to a tool from their occupation: réz 'copper' $>$ Rezed, sarló 'scythe'> Sorlou-d, vas 'iron'> Vos-sa, Vos-ca (2), Vos-od (3).

In most cases, personal names were formed with $-d(i) \sim-t(i)$ and its cluster of derivatives, $-s$ and its cluster of derivatives, $-c s$ and its cluster of derivatives, $-a /-e,-k a /-k e$ and $-i$.

In the Census of the Abbey of Tihany, the derivatives $-d$ and $-s$ are predominant in this type of name-formation. Personal names formed from common nouns denoting plants and animals were formed only with these two derivatives.

Both the linguistic creativity of name-givers and the analogy of personal names derived during the adaptation of loan names contributed to the frequent 
occurrence of derivation as a means of the formation of personal names from Hungarian common words in the Middle Ages.

\section{NAMES FORMED WITH SYNTAGMATIC CONSTRUCTION}

In this process, two existing lexemes are connected to produce a two-part personal name where both parts of the compound give some kind of information about the person, see Kis 'little' + Gazdag 'rich' > Kisgazdag etc. This method was not common in the Middle Ages but the Census of the Abbey of Tihany contains some examples of this name-forming process: Jó 'good' + Legény 'bachelor' > Jólegény (PRT. 10: Jouleken, Joulekun Jouleguin), Ma 'today' + Vagy 'you exist' > Mavagy (PRT. 10: Maogy, Mauogi, Mauogy), Nem 'no' + Él ‘lives’ > Nemél (PRT. 10: Nemel, Nemelh), Nem 'no' + Vagy 'you exist' > Nemvagy (PRT. 10: Nemuogv, Numuogi), Nem 'no' + Való 'existing'> Nemvaló (PRT. 10: Nomuolou).

As these examples show, most of these names relate to the existence of the named person. In the Middle Ages, certain elements of the ancient superstitious circle of beliefs co-existed with Christianity for a long time. Apotropaic names denying the existence of the named person are examples of this most ancient name-giving tradition in the Charter.

In this article I have presented the types of name-forming processes that were used to create personal names in the Middle Ages with the help of a single charter, the $13^{\text {th }}$ century Census of the Abbey of Tihany. The intensity of the main name-forming trends relates to both extra-linguistic factors that are predominant in the given era and the influence of internal linguistic analogies.

\section{REFERENCES}

Benkő, L. (1950). Tővégi magánhangzók rövidült keresztneveinkben. [End-of-vowels in our apocopated given names]. Magyar Nyelv, 46, 230-233.

Benkö, L. (1967). A magyar tulajdonnevek története. [The History of Hungarian Proper Names]. In G. Bárczi, L. Benkő, J. Berrár, A magyar nyelv története [The History of the Hungarian Language] (pp. 374-388). Budapest: Nemzeti Tankönyvkiadó.

Fehértói, K. (1969). A XIV. századi magyar megkülönböztető nevek [14th century Hungarian distinctive names] (Nyelvtudományi Értekezések 68). Budapest: Akadémiai Kiadó.

Hajdú, M. (2003). Általános és magyar névtan. Személynevek [General and Hungarian onomastics. Personal names]. Budapest: Osiris Kiadó.

Hoffmann, I. (2007). Helynevek nyelvi elemzése (2. kiadás) [The Linguistic analysis of toponyms (Second edition)]. Budapest: Tinta Könyvkiadó.

Hoffmann, I. (2008). A személynévrendszerek leírásához [On the description of personal name systems]. Magyar Nyelvjárások, 46, 5-20. 
Kövecses, Z. (2005). A metafora: Gyakorlati bevezetés a kognitiv metaforaelméletbe [The metaphor: Practical introduction to cognitive metaphor theory]. Budapest: Typotex Kiadó.

N. Fodor, J. (2010). Személynevek rendszere a kései ómagyar korban. A Felsö-Tisza-vidék személyneveinek nyelvi elemzése (1401-1526) [System of personal names in the old Hungarian period. The Linguistic analysis of personal names from the Upper Tisza Region (1401-1526)] (Magyar Névtani Értekezések 2). Budapest: Eötvös Loránd Tudományegyetem Bölcsészettudományi Kar.

Ok1Sz. = Szamota, I., \& Zolnai, Gy. (1902-1906). Magyar oklevél-szótár. Pótlék a Magyar Nyelvtörténeti Szótárhoz [Hungarian charter dictionary. Supplement to the Hungarian dictionary of language history]. Budapest: Magyar Tudományos Akadémia.

Pais, D. (1966). Régi személyneveink jelentéstana (2. kiadás) [Semantics of our old personal names (Second edition)]. Budapest: A Magyar Nyelvtudományi Társaság Kiadványai 115.

PRT. = Erdélyi, L., \& Sörös, P. (Ed.). (1912-1916). A pannonhalmi Szent Benedek-rend története [The history of the order St. Benedict in Pannonhalma] (Vols. 1-12). Budapest: Stephaneum.

Reszegi, K. (2009). A kognitív szemlélet lehetőségei a helynévkutatásban. A metonimikus névadás [Possibilities of the cognitive approach in toponymic research. Metonymic name-giving]. Magyar Nyelvjárások, 47, 21-41.

Reszegi, K. (2012). Cognitive Approaches to Hungarian Toponymy. Onoma, 47, 367-379.

Szegfü, M. (1991). A személynévképzés [Anthroponym formation]. In L. Benkő (Ed.), A magyar nyelv történeti nyelvtana. I. A korai ómagyar kor és elözményei. [The historical grammar of the Hungarian language. I. The early Old Hungarian age and its antecedents] (pp. 250-253). Budapest: Akadémiai Kiadó.

Tolcsvai Nagy, G. (2008). A tulajdonnév jelentése [The meaning of the proper name]. In A. Bölcskei, I. N. Császi (Ed.), Név és valóság [Name and reality] (pp. 30-41). Budapest: A Károli Gáspár Református Egyetem Magyar Nyelvtudományi Tanszékének Kiadványai 1.

Tóth, V. (2016). Személynévadás és személynévhasználat az ómagyar korban [Personal name-giving and personal name-usage in the Old Hungarian Era]. Debrecen: Debreceni Egyetemi Kiadó.

Zs. = Zsigmondkori oklevéltár $[$ Diploma Archive of the Sigismund Era] (1951-2009) (Mályusz, E. (Ed.), Vols. 1-7; Borsa, I., \& C. Tóth, N. (Eds.), Vols. 8-9; C. Tóth, N. (Eds.), Vol. 10; C. Tóth, N., \& Neumann, T. (Eds.), Vol. 11). Budapest: Magyar Országos Levéltár.

\section{SUMMARY}

In the Middle Ages, several name-formation processes played a role in the creation of the anthroponyms in Hungarian. The main name-formation mechanisms were:

1. Semantic name-formation. Within this mechanism, the anthroponym develops through the use of internal elements of the language in such a way that the anthroponymic meaning is created without any change in morphological structure. In Old Hungarian naming practices, the most frequent types of semantic name-formation were:

a. metaphoric name-giving (e.g. farkas 'farkas' [wolf] > anthroponym Farkas),

b. metonymic name-giving (e.g. when an "instrument" of a profession becomes the name of the person practising the given profession; ökör 'ökör' [ox] > anthroponym Ökör as the name of a butcher),

c. semantic split: e.g. ethnonyms, names of professions, etc., often become anthroponyms without the use of any morphological tool (kovács 'kovács' [smith] > anthroponym Kovács).

2. Morphematic construction. In the Old Hungarian period, several suffixes contributed to the creation of anthroponyms, among which the most common ones were: $-d(i) \sim-t(i),-s,-a /-e$ etc. This morphological solution was the most important tool for adapting foreign names in the Middle Ages: Petrus in Latin > Petr-i, Pet-e, Pet-i, Pet-es in Hungarian. 
3. Syntagmatic construction. This process, through the combination of two existing lexemes, creates an anthroponym composed of two constituents, in which both elements provide a certain information about the named person.

In this essay I provide an overview of the typical name-formation processes characterising the formation of anthroponyms in Old Hungarian.

Keywords: personal names, semantic name-formation, morphematic construction, syntagmatic construction 